\title{
Design and Fabrication of Electric Go-Kart
}

Aashish Porwal

Department of Mechanical Engineering

Shivajirao Kadam Institute of Technology \& Management, Indore, Madhya Pradesh, India

Karunesh Chouhan

Department of Mechanical Engineering

Shivajirao Kadam Institute of Technology \& Management, Indore, Madhya Pradesh, India

\author{
Nirmal Chohuan \\ Department of Mechanical Engineering
}

Shivajirao Kadam Institute of Technology \& Management, Indore, Madhya Pradesh, India

\section{Jhanvi Chatur}

Department of Electronics \& Communication

Shivajirao Kadam Institute of Technology \& Management, Indore, Madhya Pradesh, India

\section{DESIGN METHODOLOGY}

Abstract:- The report aims at discussing the design procedure of the Go-Kart vehicle. The report is an account of application of extensive engineering concepts, production engineering, project management and team work. The report is a submission proof that these ideas have been efficiently and viably converted into a high performance vehicle.

With the vision to eliminate the harmful gases in the air caused due to smouldering of fuel and to form a pollution-free environment, we have designed an electric go-kart.

This report is aimed at designing and developing a working model of an electric go-kart. The design and fabrication of the go-kart are made simple so that it could be operated even by non-professional drivers. The design is made keeping in mind the high strength of vehicle which can sustain more weight and provide the best facilities at a low cost.

Keywords Go-Kart, Electric vehicle, Lithium ion Battery, High performance vehicle.

\section{INTRODUCTION}

The design has been approached by considering all possible alternatives for a system by modelling them in CAD software like CREO Parametric 3.0 and analysed it on ANSYS 16.0 FEA software.

The design is mainly focused on the following objectives: Safety, Serviceability, Strength, Ruggedness, cost, durable, lightweight, high performance, ergonomics, and aesthetics.

Sub-Departments for Design:

Chassis Department

Steering Department

Brakes and Tyres Department

$\square$ Transmissions Department

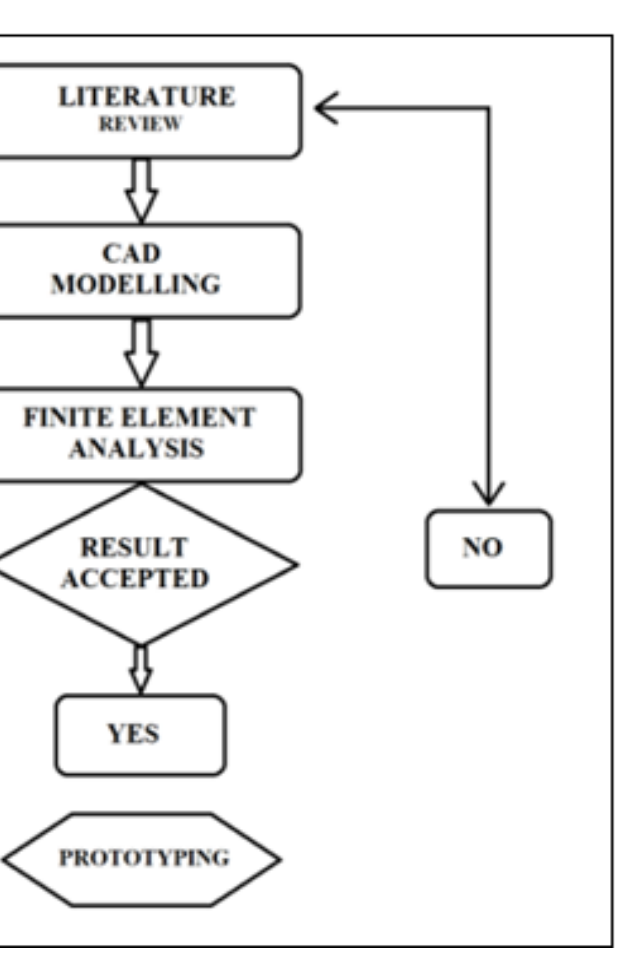

Fig.1. Design Methodology

TABLE I: COMPLETE VEHICLE SPECIFICATION

\begin{tabular}{|l|l|}
\hline Parameters & Specifications \\
\hline Overall Length & $1.90691 \mathrm{~m}\left(75.1{ }^{\prime \prime}\right)$ \\
\hline Overall Width & $1.1938 \mathrm{~m}\left(47^{\prime \prime}\right)$ \\
\hline Overall Height & $1.088 \mathrm{~m}\left(42.82^{\prime \prime}\right)$ \\
\hline Wheelbase & $1.1684 \mathrm{~m}\left(46^{\prime \prime}\right)$ \\
\hline Track Width & $0.9652 \mathrm{~m}\left(38^{\prime \prime}\right)$ \\
\hline Ground Clearance & $0.06326 \mathrm{~m}\left(2.5^{\prime \prime}\right)$ \\
\hline Max Speed & $21.37 \mathrm{~m} / \mathrm{s}$ \\
\hline Max Acceleration & $3.16 \mathrm{~m} / \mathrm{s}^{2}$ \\
\hline C.G Height & $0.1397 \mathrm{~m}\left(5.5^{\prime \prime}\right)$ \\
\hline Stopping Distance & $1.240 \mathrm{~m}\left(48.8^{\prime \prime}\right)$ \\
\hline Overall Weight & $190 \mathrm{Kg}$ \\
\hline Steering Ratio & $1: 1$ \\
\hline Weight Distribution & $35: 65$ \\
\hline Motor & $48 \mathrm{~V}, 4.5 \mathrm{KW}$ BLDC \\
\hline Battery & $48 \mathrm{~V}, 50 \mathrm{Ah} \mathrm{Li}$-ion \\
\hline Brake Disc & $0.190 \mathrm{~m}$ \\
\hline Turning Radius & $3.0214 \mathrm{~m}$ \\
\hline Ackermann Angle & $21.8^{\circ}$ \\
\hline
\end{tabular}




\section{MATERIAL SELECTION}

The material with low cost high strength and good weld ability must be used for the roll cage. After the extensive paper study of different material, we concluded to decide between SAE 1018 and SAE 4130.

Alter discussion and analysis considering the physical strength, weight, availability and cost of the material we decided to use AISI 4130 as a roll cage material.

\section{TABLE II. MATERIAL COMPARISON}

\begin{tabular}{|l|l|l|}
\hline Properties & AISI 1018 & AISI 4130 \\
\hline$\%$ carbon & $0.14-0.20$ & $0.28-0.33$ \\
\hline Density (g/cc) & 7.87 & 7.85 \\
\hline Modulus of Elasticity (GPa) & 200 & 205 \\
\hline Yield Strength (MPa) & 365 & 435 \\
\hline Ultimate Strength (MPa) & 450 & 670 \\
\hline Bulk Modulus & 140 & 140 \\
\hline Poisson's Ratio & 0.29 & 0.29 \\
\hline Elongation at Break & $15 \%$ & $25.50 \%$ \\
\hline
\end{tabular}

\section{[1] ROLL CAGE}

Calculation of Impact force:

The estimation of impact force was done by using "ImpulseChange in momentum theorem."

Impulse $=\mathrm{F} . \Delta \mathrm{t}$

Overall Weight $(\mathrm{m})=190 \mathrm{Kg}(\max$.

$\Delta \mathrm{t}=$ Impact time

F. $\Delta \mathrm{t}=\Delta \mathrm{P}$

$$
F=\frac{m * v}{\Delta t}
$$

Impulse Time $=$ Weight $*($ velocity $/$ load $)$

$$
\Delta \mathrm{t}=0.4 \mathrm{sec}
$$

A. Worst collision case

B. General Case (Real world scenario)

\section{Front Impact Tests:}

Impact load calculations regarding front impact test are as follows:

M (mass of the vehicle $=190 \mathrm{~kg}$ Driver included)

Velocity $(\mathrm{v})=90 \mathrm{Km} / \mathrm{hr}=25 \mathrm{~m} / \mathrm{sec}$

$$
\begin{gathered}
F=\frac{m * v}{\Delta t} \\
\mathrm{~F}=11875 \mathrm{~N}
\end{gathered}
$$

\section{Conclusion:-}

Deformation $=0.52997 \mathrm{~mm}$

Stress generated $=334.65 \mathrm{MPa}$

Thus in frontal collision, if the load reaches to the front most member the chassis and driver would be safe with

F.O.S $=1.148$ (considering yield point as material strength)

\section{Rear Impact Test:}

In rear collision, the vehicle is assumed to be stationary, fixed and another vehicle with same mass and collides with the former vehicle. Force is applied on rear portion of vehicle and all DOF'S of front were constrained.

$$
\begin{array}{r}
\text { Velocity }(\mathrm{v})=70 \mathrm{Km} / \mathrm{hr}=19.44 \mathrm{~m} / \mathrm{sec} \\
\mathrm{F}=9237 \mathrm{~N}
\end{array}
$$

\section{Conclusion:-}

Deformation $=0.0035142 \mathrm{~m}$

Stress generated $=490.23 \mathrm{MPa}$

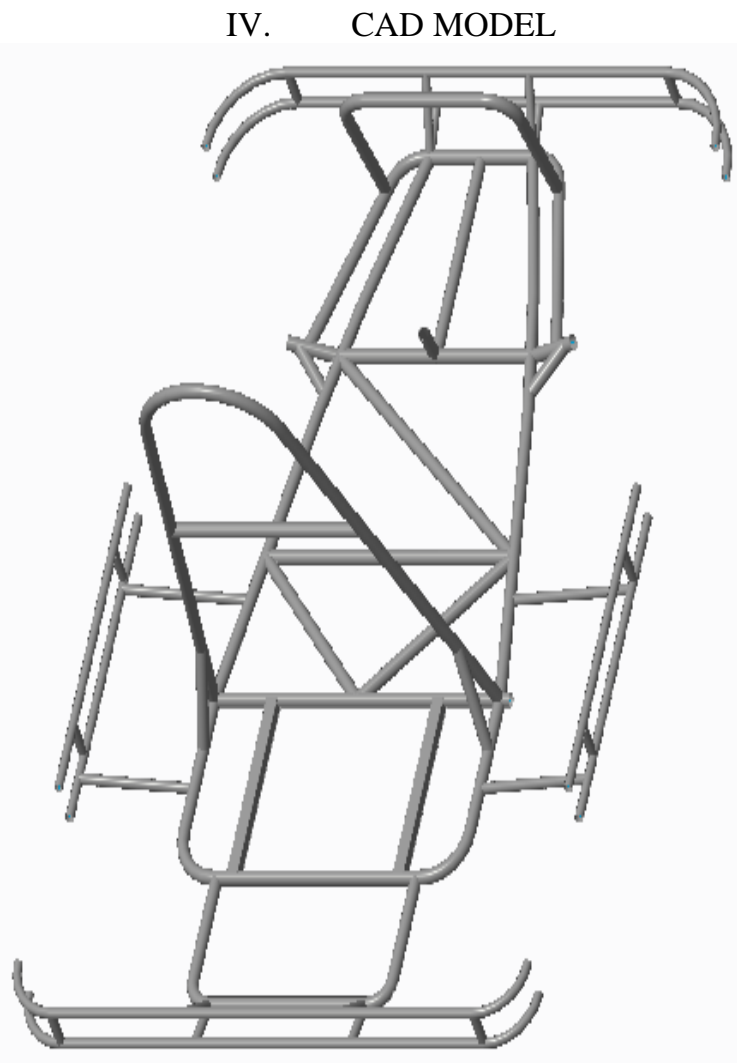

Fig.2. Isometric View Roll cage

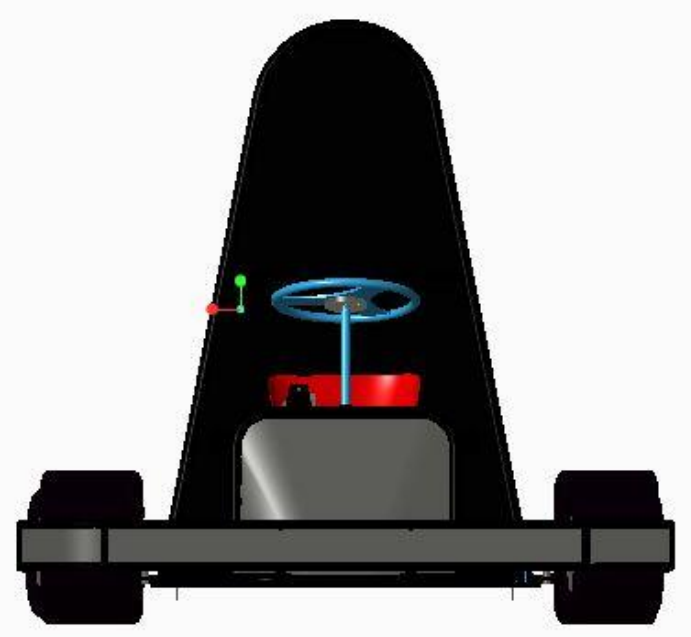

Fig.3. Front View 


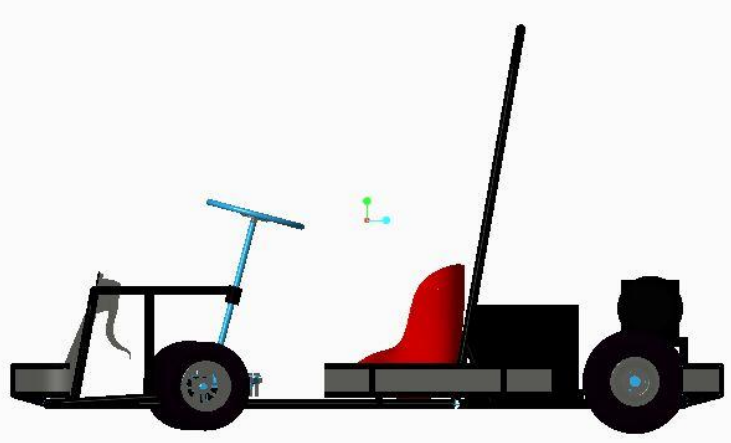

Fig.4. Left View
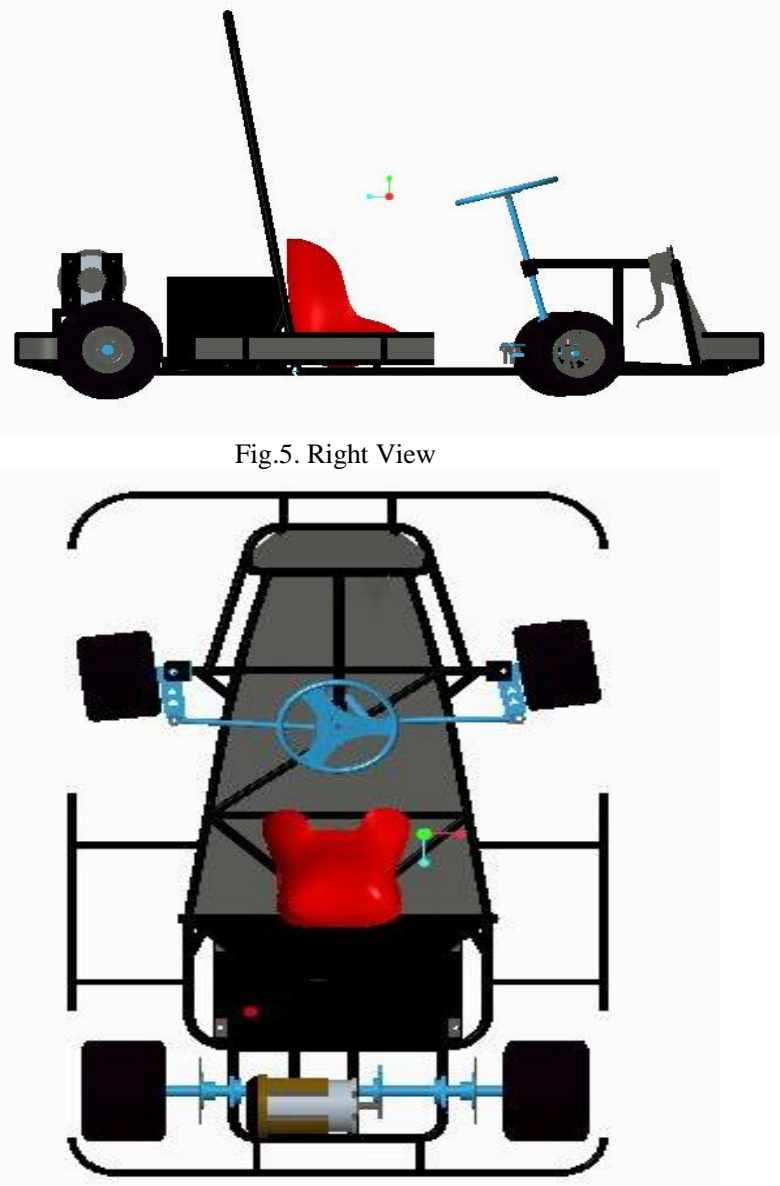

Fig.6. Top View

V. CAE ANALYSIS

A. Front Impact

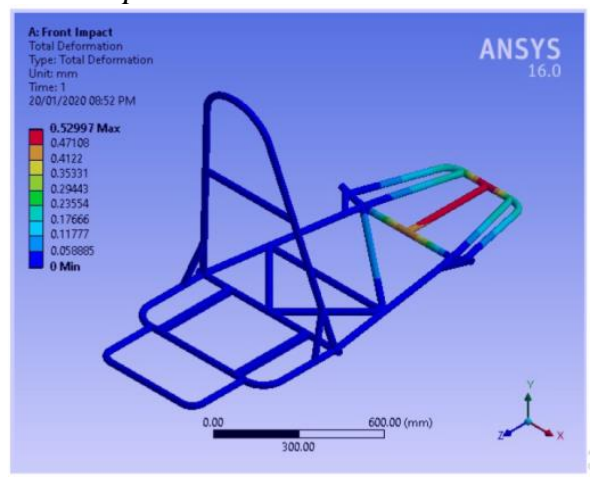

Fig.7. Total Deformation

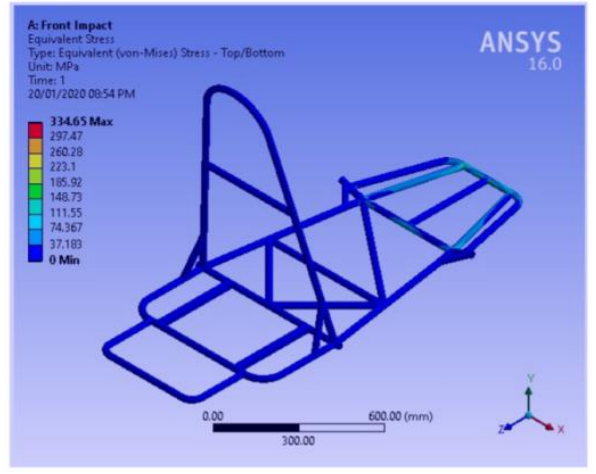

Fig.8. Equivalent Stresses

B. Rear Impact

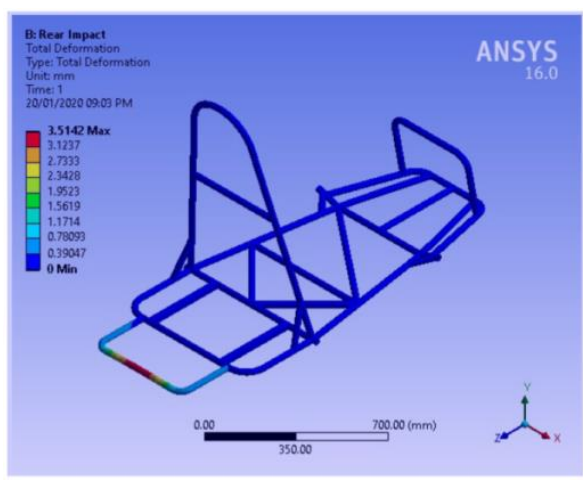

Fig. 9. Total Deformation

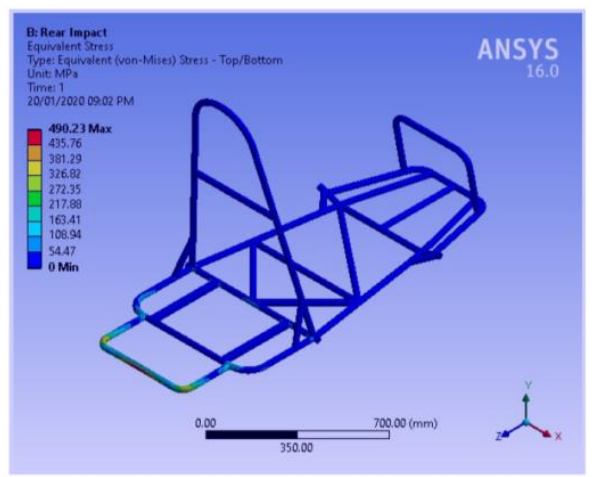

[2] STEERING

Fig.10. Equivalent Stresses

Steering system is one of the crucial mechanisms, which are responsible for a smooth maneuver controlling of the vehicle. Apart from the controlling of the vehicle, steering system is expected to display its Good Ergonomics as well as the ease of use. The primary objective of the any steering mechanism is to reduce the steering effort as possible and for that, decreasing the steering wheel travel which results in a quick responsiveness of the steering wheel. The steering geometry is Ackermann-type steering mechanisms which uses four-bar linkages.

TABLE III.

\begin{tabular}{|l|l|}
\hline Description & Values \\
\hline Wheelbase & $1.1684 \mathrm{~m}$ \\
\hline Track Width & $0.9652 \mathrm{~m}$ \\
\hline Inner Wheel Angle & $32.6^{\circ}$ \\
\hline Outer Wheel Angle & $22.2^{\circ}$ \\
\hline Turning Radius & $3.0214 \mathrm{~m}$ \\
\hline
\end{tabular}




\begin{tabular}{|l|l|}
\hline Ackermann Angle & $21.8^{\circ}$ \\
\hline Length of Tie Rod & $0.341 \mathrm{~m}$ \\
\hline Length of Stub Axle & $0.132 \mathrm{~m}$ \\
\hline Ackermann Error & 0.4 \\
\hline Steering Ratio & $01: 01$ \\
\hline Normal Force & $686 \mathrm{~N}$ \\
\hline Lateral Force & $8750 \mathrm{~N}$ \\
\hline Tractive Force & $411 \mathrm{~N}$ \\
\hline Moment of NF & $4.05 \mathrm{Nm}$ \\
\hline Moment of LF & $38.7 \mathrm{Nm}$ \\
\hline Moment of TF & $53.4 \mathrm{Nm}$ \\
\hline Torque on Kingpin & $107.3 \mathrm{Nm}$ \\
\hline Pivot Distance & $0.3579 \mathrm{~m}$ \\
\hline Camber Angle & $2^{\circ}$ \\
\hline Caster Angle & $2^{\circ}$ \\
\hline King Pin Inclination & $2^{\circ}$ \\
\hline Scrub Radius & $0.1317 \mathrm{~m}$ \\
\hline Caster Trail & $0.00433 \mathrm{~m}$ \\
\hline
\end{tabular}

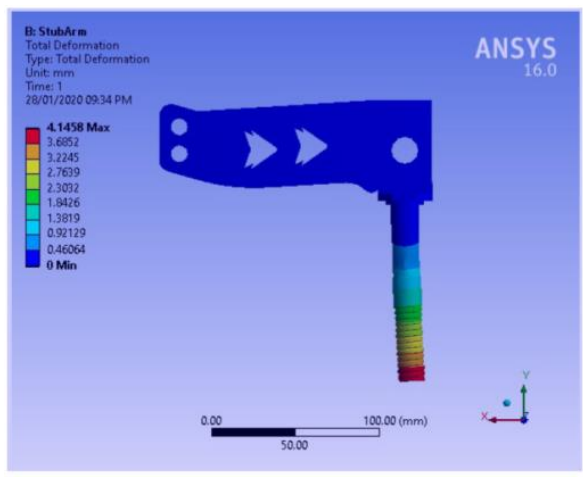

Fig.11. Stub arm Total Deformation

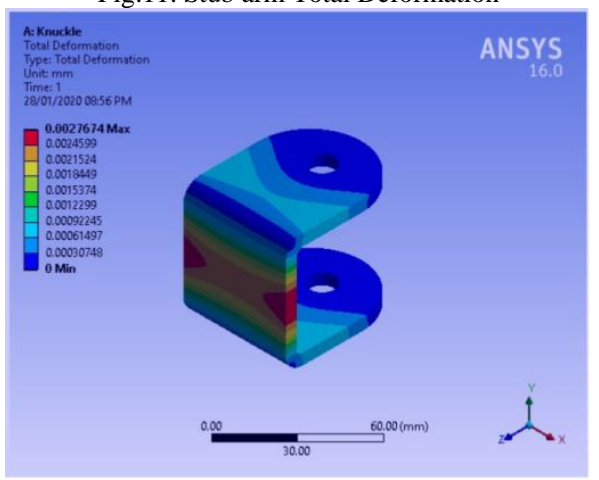

Fig.12. Knuckle Total Deformation

\section{[3] TRANSMISSION}

Electric Powertrain - EVs have a single-speed transmission which sends power from the motor to the wheels.

The motor is powered by a battery or by multiple batteries which store the electricity required to run an EV. The higher the $\mathrm{kW}$ of the battery, the higher the range.

We have used chain drive type Transmission Between motor and drive shaft. The main advantage being its lightweight, highly efficient, low maintenance characteristics.

\section{TABLE IV. TRANSMISSION SPECIFICATION}

\begin{tabular}{|l|l|}
\hline Description & Values \\
\hline Transmission Type & Chain drive \\
\hline Motor Sprocket teeth & 13 \\
\hline Shaft Sprocket teeth & 40 \\
\hline Gear Ratio & $3.08: 1$ \\
\hline Motor Peak Torque & $38 \mathrm{Nm}$ \\
\hline Motor Maximum Power & $4.5 \mathrm{KW}$ \\
\hline Motor Type & BLDC \\
\hline
\end{tabular}

\begin{tabular}{|l|l|} 
Motor Voltage & $48 \mathrm{~V}$ \\
\hline Motor Maximum rpm & 4500 \\
\hline Maximum Velocity & $21.4 \mathrm{~m} / \mathrm{s}$ \\
\hline Maximum Acceleration & $3.16 \mathrm{~m} / \mathrm{s}^{2}$ \\
\hline Torque on Wheel & $104.2 \mathrm{Nm}$ \\
\hline Transmission Efficiency & $90 \%$ \\
\hline Tyre radius & $0.14 \mathrm{~m}$ \\
\hline Total tractive effort & $143.2 \mathrm{~N}$ \\
\hline Rolling Resistance & $93.2 \mathrm{~N}$ \\
\hline Air Drag & $50 \mathrm{~N}$ \\
\hline Force at Wheels & $601.09 \mathrm{~N}$ \\
\hline
\end{tabular}

\section{[4] BRAKING SYSTEM}

The hydraulic disc brakes are used in motor vehicles to slow down its rotational motion by the help of frictional force. It is caused by pushing the brake pads against the disk rotor. It converts kinetic energy into heat energy that dissipates through the rotor vents and slows down the vehicle. Disc brake offers much better stopping performance. Advantages of Disc brake system:-

- Ability to provide more consistent frictional behaviour.

- Better braking performance at high speed.

- Ability to lose heat developed due to friction quickly.

Selection of brakes:

These are considerations and certain selections that are selected for the better and safe braking. For the vary purpose master cylinder bore diameter was taken under consideration and calculation was done. Two discs have been used at the shaft for multiplying braking force. Some selected parameters are:-

\section{TABLE VII. BRAKE SPECIFICATION}

\begin{tabular}{|l|l|}
\hline Parts & Specification \\
\hline Overall Weight & $190 \mathrm{~kg}$ \\
\hline Deceleration & $0.7 \mathrm{~g}$ \\
\hline Weight ratio & $35: 65$ \\
\hline Tire Diameter Rear & $11^{\prime \prime}$ \\
\hline Tire Diameter front & 10 "' \\
\hline Static Rear Weight & $123.5 \mathrm{Kg}$ \\
\hline Static Front Weight & $66.5 \mathrm{Kg}$ \\
\hline COF Between Tire \& Road & 0.7 \\
\hline COF Between Pad \& Rotor & 0.45 \\
\hline Wheel Base & $46 "$ \\
\hline Height of Gravity & $0.1397 \mathrm{~m}$ \\
\hline Dynamic Front Weight & $811.365 \mathrm{~N}$ \\
\hline Dynamic Rear Weight & $1052.535 \mathrm{~N}$ \\
\hline Master cylinder (bore diameter) & $0.014 \mathrm{~m}$ \\
\hline Caliper (piston diameter) & $0.028 \mathrm{~m}$ \\
\hline Number of caliper piston & 2 \\
\hline Load Applied on Brake pedal & $20 \mathrm{Kg}$ \\
\hline Pedal Ratio & $5: 1$ \\
\hline Force on Push Road & $1000 \mathrm{~N}$ \\
\hline Clamping Force & $7193.1915 \mathrm{~N}$ \\
\hline Braking Torque & $1009722.56 \mathrm{Nm}$ \\
\hline Braking Force & $722779 \mathrm{~N}$ \\
\hline Deceleration & $38.04 \mathrm{~m} / \mathrm{s}^{2}$ \\
\hline Stopping Distance & $1.240 \mathrm{~m}$ \\
\hline Stopping Time & $0.255 \mathrm{sec}$ \\
\hline Brake fluid & DOT 3 \\
\hline
\end{tabular}




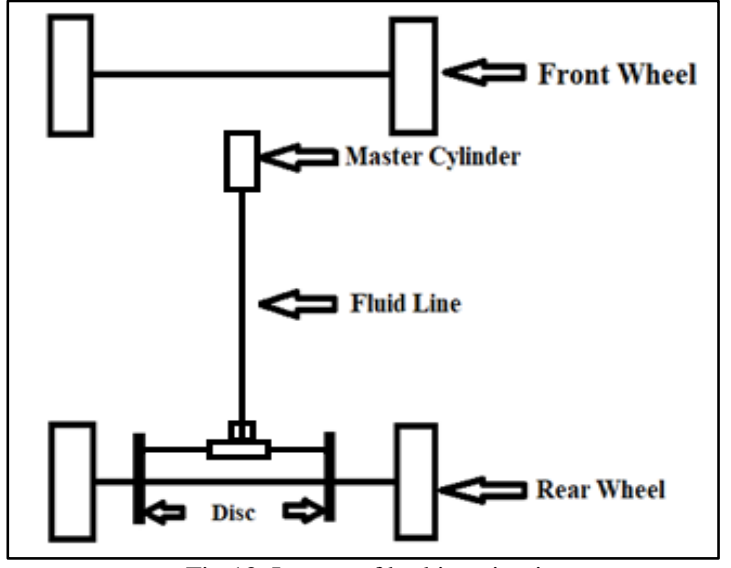

Fig.13. Layout of braking circuit

\section{[5] ELECTRICAL SYSTEM}

Objective:

The E-power train system has the following objectives are:

- To have a combustion free vehicle.

- To have agility in the performance.

- To achieve flexibility on the road.

\section{1) BLDC Motor:}

Brushless DC motors work on the same principle as that of a conventional DC motor. Due to its low noise and lightweight, it is being used for a vehicle. It requires low maintenance as well.

\section{TABLE VIII. MOTOR SPECIFICATION}

\begin{tabular}{|l|l|}
\hline Criteria & Specification \\
\hline Max power & $4.5 \mathrm{KW}$ \\
\hline Peak torque & $38 \mathrm{~N}-\mathrm{m}$ \\
\hline Max. RPM & 4500 \\
\hline Rated Current DC & $94 \mathrm{Amp}$ \\
\hline Weight & $12 \mathrm{Kg}$ \\
\hline Continues Torque & $10.8 \mathrm{~N}-\mathrm{m}$ \\
\hline Efficiency (n) & $89 \%$ \\
\hline Supply voltage & $48 \mathrm{~V}$ \\
\hline Operating Temperature & $50^{\circ} \mathrm{C}$ \\
\hline Protection & $\mathrm{IP55}$ \\
\hline
\end{tabular}

\section{2) Battery (Li-ion):-}

Lithium-ion batteries have a high energy density and are rechargeable. They are commonly used in consumer electronics. The life cycle and efficiency of Li-ion batteries are more as compared to the other rechargeable batteries.

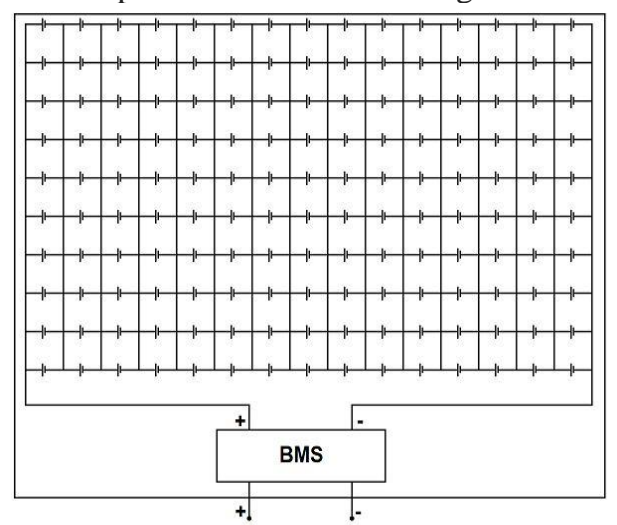

Fig 14: Battery BMS System

\section{TABLE IX. BATTERY SPECIFICATION}

\begin{tabular}{|l|l|}
\hline Supply voltage & $48 \mathrm{v}$ \\
\hline Battery capacity & $50 \mathrm{Ah}$ \\
\hline Cell voltage & $3.6 \mathrm{v}$ \\
\hline Efficiency(n) & $90 \%$ \\
\hline Weight & $34 \mathrm{~kg}$ \\
\hline Cooling system & Natural cooling \\
\hline BMS & Integrated \\
\hline Charging Time (15Amp) & $7200 \mathrm{Sec}$ \\
\hline
\end{tabular}

\section{3) Controller:}

A motor controller is a device used for operating an electric motor and is coordinated in some predetermined manner. A controller can have a manual or automatic system in order to start and stop the motor, for changing the direction of rotation from forward to reverse, for selection and regulation of speed and for limiting the torque. It is also used to protect the motor from overloads and faults.

\section{Other components:}

Fuse, Kill Switch, Contactor, FNR, Relay.

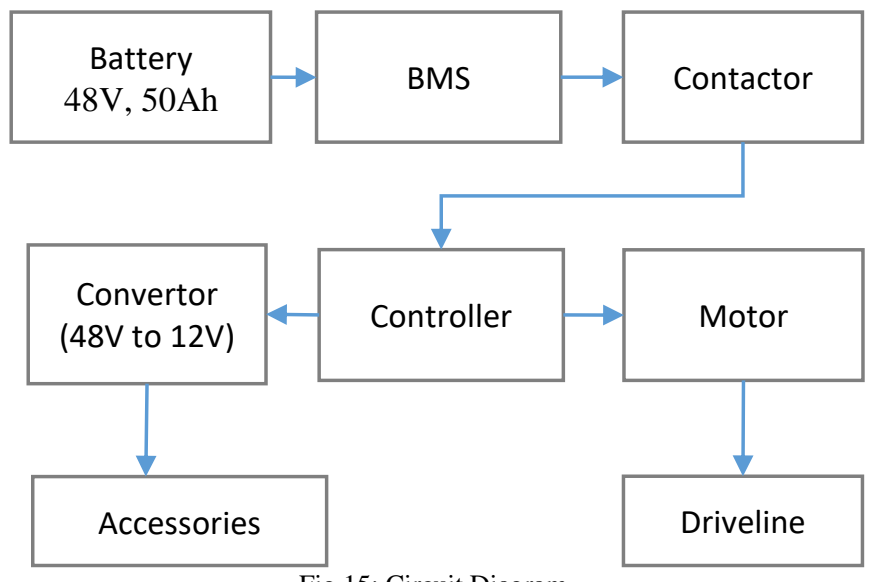

Fig 15: Circuit Diagram 


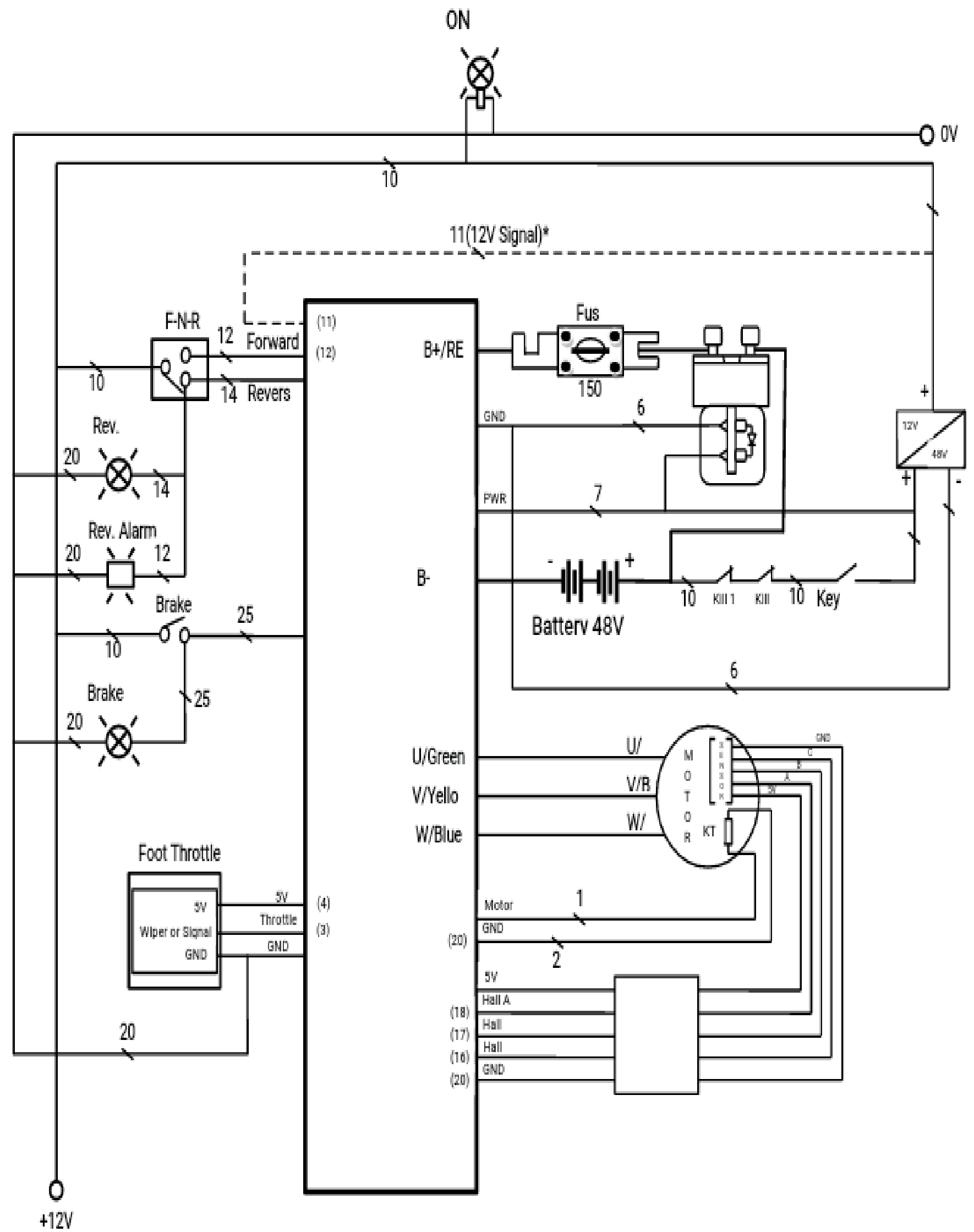




\section{VEHICLE VIEWS}

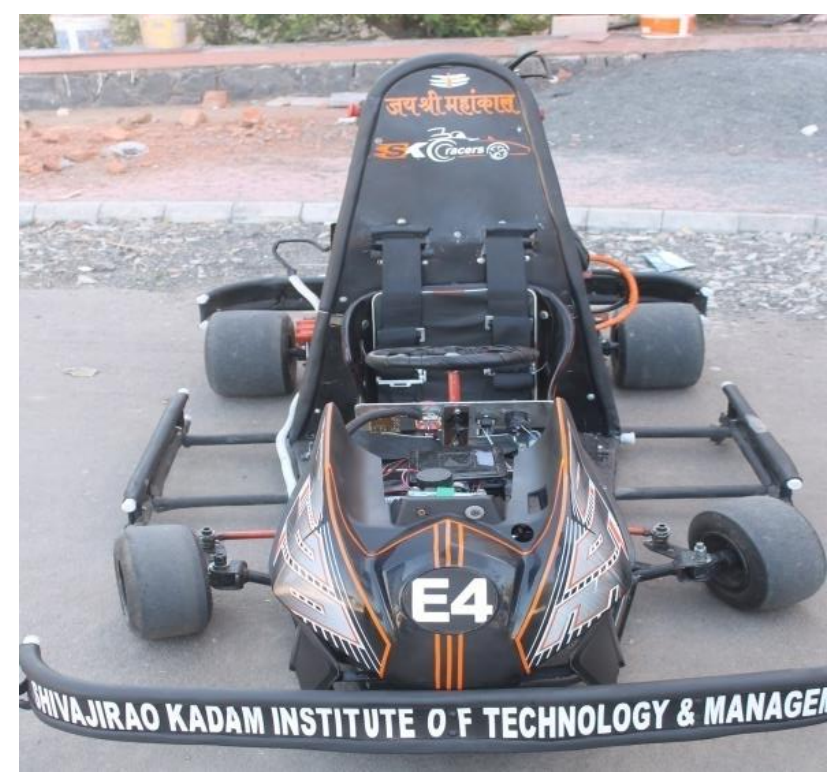

Fig.17

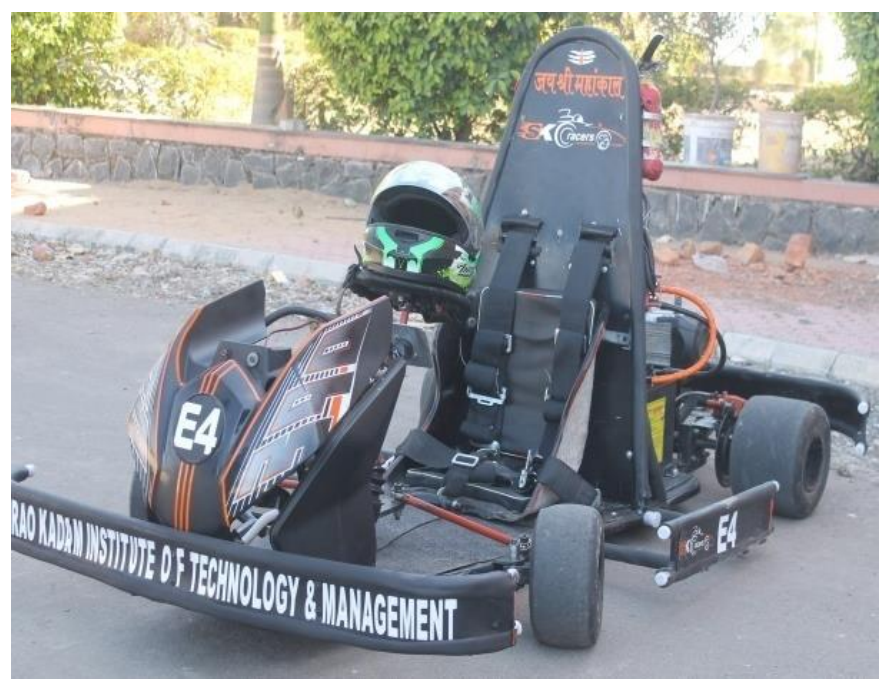

Fig.18

\section{REFERENCES}

[1] International GO-KART Championship Season 8Rules \& guideline

[2] Practical Finite Element analysis - Nitin S. Gokhale

[3] Strength of Materials - R.K Rajput

[4] https://www.machinedesign.com/news/article/21817009/howto-design-a-double-fourbar-steering-system

[5] https://www.scribd.com/doc/210560529

[6] https://www.bmikarts.com/Go-Kart-Spindles

[7] Race Car Vehicle Dynamics by Milliken D., Karsprak E., Metz L.and Milliken W. (2003).

[8] Thomas D. Gillespie "Fundamentals of Vehicle Dynamics"

[9] "Breaking system of go-kart" by IARJSET vol.4, issue 5 may 2017

[10] "Design of breaking system of go-kart"IJETER Volume 5, Issue 11, November (2017)

[11] B.Babu, M.Prabhu, P.Dharmaraj, R.Sampath 2014 Stress Analysis of Steering Knuckle of AutomobileSteering System International Journal of Research in Engineering and Technology.

[12] Advance vehicle Technology by HeinsHeisler 